\title{
NANOPARTICLE FERRIFEROUS HYDROSOL AS AN ADVANCED REAGENT FOR WASTE WATER TREATMENT
}

\author{
Danas Budilovskis \\ Mudis Šalkauskas \\ Center of Sciences and Technologies, INECO, Sauletekio 15-509, Vilnius,
}

Lithuania

\begin{abstract}
A new procedure for electroplating waste water treatment using a waste iron scrap by-product for nanoparticle ferriferous hydrosol (FFH) preparation is presented. FFH which contains $\mathrm{Fe}(\mathrm{II})$ and $\mathrm{Fe}$ (III) was employed for neutralization and heavy metal removal from electroplating wastewater as well as for decontamination of concomitant pollutants such as phosphates, organic compounds, residual oils, dyes and detergents. It is possible due to the simultaneous operation of several different mechanisms: sorption, coagulation, reduction, fertilization and etc. The method is suitable for the purposes of waste water treatment and disposal in compliance with environmental laws and is implemented in some East and West European countries. The results were proved in accredited laboratories in various countries. According to the composition of its water extractable fraction, remaining waste sludge could be safely deposited in urban waste repositories or used as a raw material for production of various technically useful products such as ceramics, pigment, etc. Treated water may be reused in technological processes.
\end{abstract}

\section{KEYWORDS}

Nanoparticles; Ferriferous hydrosol (FFH); Waste water treatment; Sludge.

\section{INTRODUCTION}

Current ecological situation in the world stimulates rapid development of ecological technologies which enables industrial factories to comply with strict standards and laws of environment protection. At the beginning of $21^{\text {st }}$ century the market of such products reach 900 billion dollars and in 2005 it comprises more than 1200 billion dollars. The leaders here are USA, Japan and Germany [1]. The most actual problem is development of technically and financially available technologies know as Best Available Technologies (BAT) for certain environmental problems [2].

The environment protection requirements for industrial wastewaters strictly limit the concentration of impurities and contaminants in discharged water and therefore now there are numerous methods for sewage treatment. Of special interest is the wastewater method for elimination of heavy metals from electroplating and printed circuit production shops [3]. Electroplating wastes are potentially hazardous to human health and the environment when they are improperly managed. Several special and hazardous wastes are commonly generated 
by the electroplating industry. Generally, electroplating is only one step in the processes at a captive shop (metal finishing shop).

The most common treatment for such savage is application of chemical reagent which makes it possible to precipitate heavy metal ions and separate sludge from the treated water. The technology is rather simple and effective as all heavy metals are separated by proper control of $\mathrm{pH}$ as insoluble in water hydroxides. However, some metals are amphoteric and when savage contains some special lygands which may interfere sedimentation of metal hydroxides.

Investigations of Lithuanian scientists revealed that crucial role in heavy metal ion decontamination belong to the iron colloidal suspension. Such reagent may be prepared separately and could be dosed accordingly needs in the process of wastewater decontamination. Therefore, a technology for production of ferriferous colloidal suspension (FFH) under stable technologically preferable condition was developed. The effectiveness of wastewater treatment by FFH technology may be attributed to BAT and to effective use of the outstanding properties of nanoparticles.

Nanoparticles of FFH have very large surface that contains chemically active groups therefore acts as specific adsorbents. The treated wastewater is not contaminated by additive salts and therefore it my be reused in technological process. Toxicity tests by daphnia revealed that it is non-toxic.

Sludge after wastewater treatment by FFH is low-toxic and have stable structure of ferrite spinel. As far as it contains large quantity of iron it is useful as second raw material for many industrial applications. In Lithuania it is used as an additive to industrial ceramic materials. Later it was elaborated technologies for production of pigments. In such manner there are a safe environmental technology and the resource saving industry process $[6,7]$.

Wastewater after treatment by FFH complies with the all environmental norms and products of treatment may be discharged or reused in industrial processes.

\section{PRODUCTION OF FFH}

The ferriferous hydrosol (FFH) nanoparticles are generated by means of electrolysis. Waste iron scrap is placed in special anodic compartment and dissolved. For intensification of process and stabilization of colloidal nanoparticles solution contains special additive. In the electrochemical process of iron oxidation in the solution occurs iron ions and they are there hydrolyzed. In the vicinity of iron anode chemical processes can be divided in several stages: generation of $\mathrm{Fe}^{2+}$ on the surface of anode, diffusion of ions into solution, hydrolysis and formation of insoluble nanoparticles by interactions of components in solution.

Insoluble phase formation proceeds via compounds of various coordination types which are converted to the other ones. It may be expressed as migration of $\mathrm{Fe}^{2+}$ from the anode accompanied by oxidation of $\mathrm{Fe}^{2+}-\mathrm{e}^{-} \rightarrow \mathrm{Fe}^{3+}$, and by hydrolysis $\mathrm{Fe}^{2+}+2 \mathrm{H}_{2} \mathrm{O} \rightarrow \mathrm{Fe}(\mathrm{OH})_{2}+$ $2 \mathrm{H}^{+}$. Iron (II) hydroxide is oxidized by the oxygen dissolved in electrolyte $4 \mathrm{Fe}(\mathrm{OH})_{2}+2 \mathrm{H}_{2} \mathrm{O}$ $+\mathrm{O}_{2} \rightarrow 4 \mathrm{Fe}(\mathrm{OH})_{3}$.

Thus, formation of sediments in the process of anodic dissolution of iron is based on the hydrolysis of iron ions and their polycondensation till the formation of polynucleous hydroxo complexes, which in the process of nucleation aggregate into the small particles of irregular 
structure. Further in the process of ageing, soles, gels and sediments are formed in such a nanodispersion system. The method of polycondensation described above, or as it is called now the zol-gel method requires solution over saturation with a new phase formed material. The zol-gel technology in comparison with the traditional one has such a peculiarity which allows obtaining of homogenous product of regular structure in the beginning stages and it is possible to change the reological properties of the dispersed phase in a wide range.

Investigation by using the electron microscopy and electron diffraction methods have revealed that fresh FFH is composed of amorphous particles of from several nanometers up to $100 \mathrm{~nm}$ in size (Fig.1). Therefore FFH as other polyvalent metal hydroxides, which are obtained by the zol-gel method, belongs to the nanoparticle materials, which have very wide application due to their polymeric nature, highly developed surfaces and functional $\mathrm{OH}$ groups. All this enables to modify their highly reactive surfaces by means of adsorption.

FFH is a compound of not very well defined composition and structure as it is formed in process of iron ions hydrolysis and polymerization in aqueous electrolyte solutions. All these processes end up with formation of a high dispersion solid phase of nanoparticles by the zolgel method. Such systems, have surplus of surface energy and therefore are especially highly reactive and adsorptive.

\section{WASTE WATER TREATMENTS}

The performance of wastewater treatment with FFH instead of conventional existing techniques were studied with the goal to achieve a higher removal capacity, in the treatment of metal ions $\left(\mathrm{Cu}^{2+}, \mathrm{Zn}^{2+}, \mathrm{Ni}^{2+}, \mathrm{Cd}^{2+}, \mathrm{Cr}(\mathrm{VI})\right.$ and etc. $)$ containing wastewater. The results obtained with synthetic wastewater revealed that the most effective removal capacities of studied metals could be achieved when the pH was kept between 7 and 9 (Figurel) which is required to reduce metal ion concentrations under the admissible legal levels. The process was successfully applied to treatment of an electroplating and printed circuit production wastewater where an effective reduction of $\left(\mathrm{Cu}^{2+}, \mathrm{Zn}^{2+}, \mathrm{Cr}(\mathrm{VI})\right.$ and etc. concentrations) (Table 1) under legal limits was obtained, just after 10-20 min. The method was found to be highly efficient and relatively fast and cheep compared to reagent treatment (Table 2). The most outstanding features of wastewater treatment by FFH is possibility to treat various wastewaters in one stream and cleaned water may used as technical one or included in water circulation system. The cleaned water fit all EU norms for wastes and has no toxic features. Investigations of German enterprise Informationstechnik und Umweltdienstungtungen in Kempen approved high quality of wastewater treatment by means of FFH (Table1). 

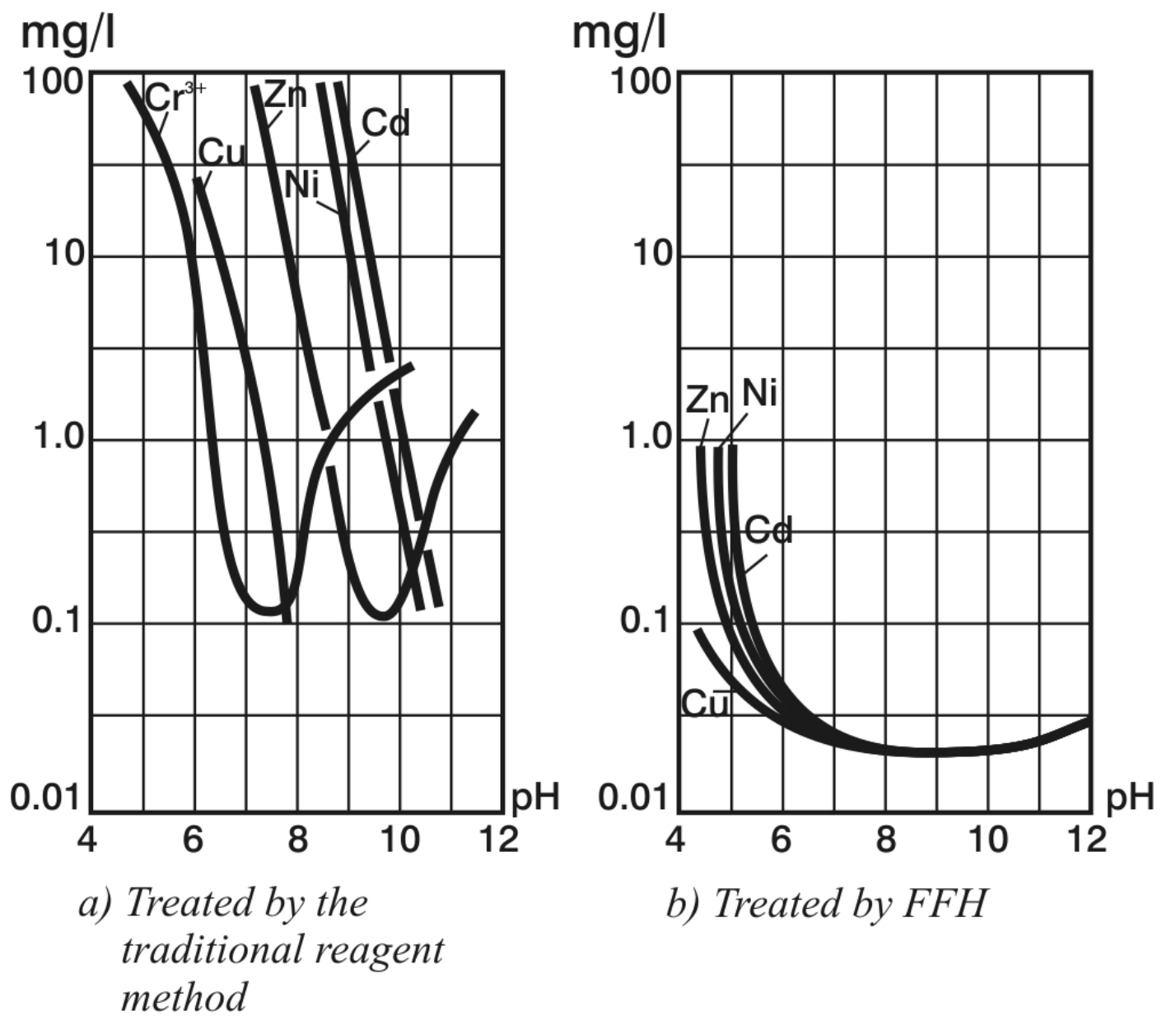

Figure 1. Sedimentation curves of wastewater heavy metal ions:
a) treated by traditional reagent method;
b) treated by $\mathrm{FFH}$

Table 1 Wastewater treatment by means of FFH results

\begin{tabular}{|l|l|l|l|}
\hline Type of wastewater & Metal ion & Concentration, $\mathrm{mg} / \mathrm{l}$ \\
\cline { 3 - 4 } & & Before treatment & After treatment \\
\hline \multirow{3}{*}{ Electroplating shop } & $\mathrm{Zn}$ & 23.1 & 0.005 \\
\cline { 2 - 4 } & $\mathrm{Cr}$ & 96.0 & 0.01 \\
\cline { 2 - 4 } & $\mathrm{Cu}$ & 46.0 & 0.01 \\
\hline \multirow{5}{*}{ Printed circuit production } & $\mathrm{Zn}$ & 0.31 & 0.002 \\
\cline { 2 - 4 } & $\mathrm{Pb}$ & 1.56 & 0.05 \\
\cline { 2 - 4 } & $\mathrm{Ni}$ & 1.05 & 0.05 \\
\cline { 2 - 4 } & $\mathrm{Fe}$ & 113.0 & 0.005 \\
\hline
\end{tabular}


Table 2 Comparison of wastewater treatment traditional reagent and by FFH

\begin{tabular}{|l|l|l|}
\hline Criteria of technology evaluation & $\begin{array}{l}\text { Traditional reagent } \\
\text { wastewater treatment }\end{array}$ & Wastewater treatment by FFH \\
\hline $\begin{array}{l}\text { Achievement of maximal allowable } \\
\text { concentration }\end{array}$ & Achieve minimal norms & $\begin{array}{l}\text { Achieve EU norms and an order } \\
\text { lover }\end{array}$ \\
\hline Reuse of water in process & Impossible & $\begin{array}{l}\text { Reuse in technical or reversible } \\
\text { water system }\end{array}$ \\
\hline Cleaned water quality & $\begin{array}{l}\text { High concentration of salts. } \\
\text { Toxicity test with daphnia } \\
\text { negative }\end{array}$ & $\begin{array}{l}\text { Low concentration of salts. } \\
\text { Toxicity test with daphnia } \\
\text { positive }\end{array}$ \\
\hline Sludge deposition & In hazardous landfills & In ordinary landfills \\
\hline Sludge utilization & Impossible & $\begin{array}{l}\text { For production of technically useful } \\
\text { materials }\end{array}$ \\
\hline Use of toxic reagents & $\begin{array}{l}\text { Acids, alkali, sodium bisulphate, } \\
\text { etc. }\end{array}$ & $\begin{array}{l}\text { Small quantity of alkali for pH } \\
\text { controle }\end{array}$ \\
\hline $\begin{array}{l}\text { Separate wastewater treatment } \\
\text { and chromium wastes }\end{array}$ & $\begin{array}{l}\text { Separate treatment of acid-alkali } \\
\text { an one stream }\end{array}$ \\
\hline $\begin{array}{l}\text { Variety of pollutants } \\
\text { Settlement dependence on pH }\end{array}$ & $\begin{array}{l}\text { For different metals different } \\
\text { ranges }\end{array}$ & All within the same interval \\
\hline $\begin{array}{l}\text { Is possible use in the presence of } \\
\text { metal metal ions, dyes, detergents, } \\
\text { complex lygands } \text { in }\end{array}$ & No & Yes \\
\hline Is it necessary to use a settler & Yes & No \\
\hline
\end{tabular}

\section{WASTEWATER TREATMANT SLUDGE}

Wastewater treatment by FFH produces sludge which has a specific composition depending on the wastewater peculiarities and the conditions of metal treatment at the mechanicalengineering enterprises, metal-working shops and iron and steel plants. The sludge is a past substance of black, dirty greenish or brown color in depending on its composition, namely on the amount of iron (II), iron (III), chromium, nickel and copper. Table 3 presents the chemical composition of sludge after wastewater treatment by FFH at the different enterprises in Lithuania, Byelorussia, Poland, Spain and etc

Table 3 Chemical composition of wastewater treatment by FFH sludge dried at $105^{\circ} \mathrm{C}$

\begin{tabular}{|l|l|l|l|l|l|l|l|l|l|}
\hline \multirow{2}{*}{ № } & Factory & \multicolumn{6}{l|}{ Content (mass.\%) } \\
\cline { 3 - 10 } & & $\mathrm{Fe}_{2} \mathrm{O}_{3}$ & $\mathrm{FeO}$ & $\mathrm{ZnO}$ & $\mathrm{Cr}_{2} \mathrm{O}_{3}$ & $\mathrm{CuO}$ & $\mathrm{NiO}$ & $\mathrm{H}_{2} \mathrm{O}$ & Others \\
\hline 1 & No 1 & 51.2 & 7.8 & 8.0 & 3.4 & 4.2 & 3.8 & 14.6 & 7.2 \\
\hline 2 & No 2 & 50.5 & 4.3 & 14.3 & 3.3 & 0.8 & 0.9 & 18.1 & 7.3 \\
\hline 3 & No 3 & 59.4 & 5.5 & 11.8 & 2.4 & 2.3 & 2.4 & 10.2 & 5.1 \\
\hline
\end{tabular}

The precipitate obtained during sewage treatment by using FFH is a mixture of iron oxihydrates with the absorbed metal compounds which are present in sewage waters magnetite $\mathrm{Fe}_{3} \mathrm{O}_{4}$ and possibly ferrites with a general formula $\mathrm{Me} \mathrm{Fe}_{3} \mathrm{O}_{4}$. Besides as mentioned in [7], there may be also amorphous heteropolycompounds, possessing molecular links, among them $\mathrm{Fe}(\mathrm{Me})(\mathrm{OH})-\mathrm{O}-$, together with hydroxo forms of divalent and trivalent cations. 
Wastewater sludge were investigated by Informationstechnik und Umveltdienstleistungen in Kempen according the standard DEV-S4. The results are presented in Table 4.

Table 4. Wastewater treatments by different methods sludge elutes

\begin{tabular}{|l|l|l|}
\hline \multirow{2}{*}{ Metal } & \multicolumn{2}{|l|}{ Metal concentration in eluate of different sludge, $\mathrm{mg} / \mathrm{l}$} \\
\cline { 2 - 3 } & Traditional method & Method by FFH \\
\hline $\mathrm{Zn}$ & 250 & 0.01 \\
\hline $\mathrm{Pb}$ & 0.05 & 0.05 \\
\hline $\mathrm{Ni}$ & 2.50 & 0.05 \\
\hline $\mathrm{Fe}$ & 0.01 & 0.01 \\
\hline $\mathrm{Cr}$ & 5.4 & 0.01 \\
\hline
\end{tabular}

Electron microscopy studies have shown that dried sludge makes a highly dispersed material with a distinctive tendency to agglomeration. Sludge particles have an irregular shape close to the spherical one. Their size is approximately 0.2-0.8 $\mu \mathrm{m}$. Besides, the studied sludge specimens contain a considerable amount of a finer fraction.

Numerous toxicity tests of sludge performed by Lithuanian and Byelorussian state authorities confirmed that the sludge of electroplating wastewater treatment by means of FFH is lowtoxic and it may be deposited in common land fields or used for manufacturing as a raw material. Health Care Ministry of Byelorussia in 5 June of 2006 confirmed that such sludge tested by the phytotoxicity test, by Tetrahymena pyroformis and Salmonella typhimurium (Eims test) and by test with mice ( $\mathrm{DL}_{50}>5000 \mathrm{mg} / \mathrm{kg}$ ) confirmed that integral evaluation of toxicity is very low and it may be attributed to the 4-th class of toxic materials. It has no mutagenic activity and have very low cumulative characteristic (coefficient up to 5).

On the basis of chemical composition of sludge it is possible to predict that it is rather useful raw material for production of iron containing pigments modified by chromium, zinc, cooper and other metals or as an additive to ceramic materials.

\section{CONCLUSIONS}

Invention of such a smart product as nanoparticle coagulant ferriferous hydrosol which is makes it possible to improve the waste water treatment technology and achieve higher parameters of cleaned water quality up to the possible reuse of it and as well as to use lowtoxic sludge for production of technically useful materials such as pigments. A preferable field of application of FFH is sewages from electroplating shops and printed circuit production, but it may be applied to waste waters of tanneries and furriery works, textile manufacture, printing works, dyes industry, wood impregnation and etc. It is also possible to use the FFH nanoparticle composition for the pretreatment of municipal wastewaters and in the process of preparation of drinking water [6-8]. The process of electroplating shop wastewater treatment by FFH is implanted in some East and West European countries.

It is possible to work with FFH in traditional reagent waste water treatment stations, using the existing equipment. The set of equipment which is employed for the realization of the technology side by alongside the standard units has special electrolysers for obtaining the FFH coagulant from iron waste and reactors for conducting the reaction of sewage neutralization-decontamination which are worked out taking into account the specific properties of the nanoparticle coagulant FFH. 
The offered technology differs from the classical methods of reagent decontamination and wastewater cleaning which use such chemicals as quicklime, sodium bisulphate or ferrous salts, sodium hydroxide and etc. Electrically generated nanoparticle composition FFH is practically safe and non-toxic reagent and therefore its use introduces very small quantities of anions into the sewage treated by it. The hygienic conditions for workers in wastewater treatment station are better; there are no problems with transportation of toxic materials. The presence of various metal ion lygands (pyrophosphates, EDTA, ammonium and others) in wastewater is no impediment to metal ion neutralization and decontamination attained of utmost admissible norms. There is no need to dividing of wastewater into chromium bearing and acid-alkaline components and there is no need to use settlers to increase sedimentation as far as the FFH is a coagulant.

The capital outlays, electric energy consumption and the working area are the same as in the traditional reagent method. The quality of wastewater treatment is improved due to the use of series of chemical and physicochemical effects which are involved in the interaction of FFH with the ions of metals and hydroxide ions in wastewater. The $\mathrm{pH}$ of water after treatment is 8.5-9 and as far as it contains low concentration of salts it is possible uses it in technological process. The sludge of wastewaters treatment is low-toxic of 4 classes and as a iron reach material may be used for manufacturing of technical products such as ceramics, pigment, engobe or glaze.

\section{REFERENCES}

[1] Gunstige Vorzeichen, Secundare Rohstoff, 2001.18 S. 148-149.

[2] Resa J. et al.; 2000. Best available technologies for water treatment. Water Resources, 34(5), 1714-1726.

[3] Budilovskis J.; 1996. FFH as reagent for waste water treatment. Ekologia $i$ promishlennost Rosii, 8, 12-15 (in Russian)

[4] Budilovskis D. and Eshchenko L. S.; 2004. Sludge of waste water treatment by FFH. Zhurnal prikladnoi khimii, (77)9, 1520-1524. (in Russian)

[5] Budilovskis D. et al; 2004. Composition of sludge from waste water treatment by FFH.Khimicheskoe i neftegazovoe mashinostroenie, 11, p. 36-38. (in Russian)

[6] Budilovskis J., 1990. The economist of Lithunia , 2, 49.

[7] Budilovskis J., 1991. The economist of Lithunia, 3, p.61.

[8] Budilovskis J., 1993. Medio ambiente; 5,. 54-56 . 